\title{
Regulation of the photosynthetic electron transport and specific photoprotective mechanisms in Ricinus communis under drought and recovery
}

\author{
Milton C. Lima Neto $^{1}$ - Joaquim Albenísio G. Silveira ${ }^{2}$ João V. A. Cerqueira ${ }^{2}$ • \\ Juliana R. Cunha ${ }^{2}$
}

Received: 10 August 2016/Revised: 17 July 2017 / Accepted: 20 July 2017/Published online: 27 July 2017

(C) Franciszek Górski Institute of Plant Physiology, Polish Academy of Sciences, Kraków 2017

\begin{abstract}
Ricinus communis is one of the major commercial non-edible oilseed crops grown in semiarid and arid environments worldwide and is reported as a drought tolerant species. Surprisingly, little is known about the mechanisms achieving this tolerance, especially in relation to photoprotection. The aim of this study was to analyze the association of the regulation of the photosynthetic electron transport and photoprotective mechanisms with drought tolerance in $R$. communis. Drought induced decreases in the relative water content, water potential and growth in $R$. communis exposed to 9 days of drought. After 6 days of rehydration, these parameters were completely recovered, demonstrating a potential of drought tolerance in this species. In addition, drought inhibited photosynthesis by stomatal and metabolic limitations ( $V_{\mathrm{cmax}}, J_{\max }$, and Rubisco activity), with partial recovery after rehydration. Leaves displayed transient photoinhibition after 6 days of drought, which was completely recovered after 6 days of dehydration. The effective quantum yields and the electron transport rates of PSII and PSI were modulated to face drought avoiding the excess energy produced by decreases in $\mathrm{CO}_{2}$ assimilation. NPQ was increased during drought, and it was maintained higher than control after the recovery treatment. In addition, the estimated cyclic electron flow was induced under drought and decreased after
\end{abstract}

Communicated by M. Garstka.

Milton C. Lima Neto

miltonlimaneto@clp.unesp.br

1 Biosciences Institute, São Paulo State University, UNESP, Coastal Campus, Praça Infante Dom Henrique s/n, P.O. Box 73601, São Vicente, SP 11380-972, Brazil

2 Plant Metabolism Laboratory, Department of Biochemistry and Molecular Biology, Federal University of Ceará, P.O. Box 6004, Fortaleza, Ceará CEP 60455-970, Brazil recovery. Photorespiration was also increased under drought and maintained at higher levels after the recovery treatment. Furthermore, antioxidative enzymes activities (SOD, APX, and CAT) were increased under drought to avoid ROS harmful effects. Altogether, we clearly showed that the modulation of photoprotective mechanisms and antioxidant enzymes are crucial to this species under drought. The implication of these strikingly strategies to drought tolerance is discussed in relation to agricultural and natural systems.

Keywords Antioxidative metabolism - Cyclic electron flow $\cdot$ Drought $\cdot$ Photochemical activity $\cdot$ Photorespiration . Ricinus communis $\cdot$ ROS

$\begin{array}{ll}\text { Abbreviations } \\ \Psi_{\mathrm{w}} & \text { Water potential } \\ \text { APX } & \text { Ascorbate peroxidase } \\ \text { CAT } & \text { Catalase } \\ \text { CEF } & \text { Cyclic electron flow } \\ \text { DM } & \text { Dry matter } \\ \text { FM } & \text { Fresh matter } \\ \text { GO } & \text { Glycolate oxidase } \\ \text { LEF } & \text { Linear electron flow } \\ \text { PET } & \text { Photosynthetic electron transport } \\ \text { PPFD } & \text { Photosynthetic photon flux density } \\ P \text { R } & \text { Photorespiration } \\ \text { ROS } & \text { Reactive oxygen species } \\ \text { RuBP } & \text { Ribulose 1,5 bisphosphate } \\ \text { RWC } & \text { Relative water content } \\ \text { PSI } & \text { Photosystem I } \\ \text { PSII } & \text { Photosystem II } \\ \text { SOD } & \text { Superoxide dismutase } \\ \text { TBARS } & \text { Thiobarbituric acid reactive substances } \\ \text { VPD } & \text { Vapor pressure deficit }\end{array}$




\section{Introduction}

Drought negatively impacts plant growth and development by disturbing several physiological process, such as photosynthesis and redox homeostasis (Flexas et al. 1999; Noctor et al. 2014). In fact, photosynthetic responses to drought are complex comprising a coordination of several morphological and physiological processes at different time scales and growth stage (Ogbaga et al. 2014). The ability to maximize water extraction from the soil, minimizing loss from leaves, is vital to plant tolerance to drought. Therefore, physiological adaptations to drought are related with changes in stomata density to maintain water status (Chaves et al. 2009), the accumulation of compatible solutes, as carbohydrates and amino acids, to lower the water potential and improve water uptake (Mcdowell et al. 2008) and the maintenance of photosynthetic efficiency by photoprotective mechanisms (Goh et al. 2011).

Photosynthetic responses to drought are influenced by the intensity, duration, and rate of progression of this stress (Zivcak et al. 2013). First, drought impairs photosynthesis through decreasing $\mathrm{CO}_{2}$ availability to chloroplasts by stomatal and mesophyll restrictions. With the progression of the stress, the Calvin-Benson cycle reactions are affected leading to limitations on photosynthetic metabolism (Flexas et al. 2012). The $\mathrm{CO}_{2}$ assimilation by the Calvin-Benson reactions is the main sink for the NADPH and ATP produced by the photosynthetic electron transport. Impairments on this important sink commonly induces an imbalance in the overall photosynthetic process, producing excessive energy in the thylakoids that could lead to an overproduction of reactive oxygen species (ROS) and eventually to photoinhibition (Takahashi and Murata 2008). Absorbed excessive energy is defined when it exceeds the capacity of photosynthesis to use it for assimilation (Murchie and Niyogi 2011). Although excess energy is potentially harmful, plants have several photoprotective mechanisms to manage the absorbed light and avoid ROS unbalance (Pérez-Torres et al. 2007).

The redox state in plant cells should be maintained in adequate levels by a delicate balance between ROS production and the scavenge system (Suzuki et al. 2012). Alterations in energy balance during drought in chloroplasts promote the generation of singlet oxygen $\left({ }^{1} \mathrm{O}_{2}\right)$ at PSII by excited triplet-state chlorophyll when the photosynthetic electron transport (PET) chain is overreduced (Nishiyama et al. 2006). In PSI, under excessive energy, electron transfer to oxygen might cause the production of $\mathrm{H}_{2} \mathrm{O}_{2}$ via radical superoxide $\left(\mathrm{O}_{2}^{-}\right)$(Asada 2006). To avoid oxidative stress, chloroplasts scavenge ROS effectively by multiple enzymatic and non-enzymatic mechanisms including superoxide dismutase (SOD), ascorbate peroxidase (APX), ascorbate, carotenoids, among others (Blokhina et al. 2003). However, these mechanisms are energetically demanding, requiring the synthesis of high amounts of antioxidants and enzymes (Stepien and Johnson 2009). An alternative strategy to avoid ROS burst is the regulation of the photosynthetic electron transport (Goh et al. 2011), avoiding photoinhibition and the excess energy in the thylakoids membranes (Lima Neto et al. 2014).

The dissipation of excess absorbed light into heat by the non-photochemical quenching (NPQ) represents a fast response of the photosynthetic membrane to excess light (Carvalho et al. 2015). A rapidly reversible component of NPQ (qE) dissipates the excess absorbed light energy in the light-harvesting antenna of PSII. $\mathrm{qE}$ is triggered by low thylakoid lumen $\mathrm{pH}$ and high $\Delta \mathrm{pH}$ generated by the photosynthetic electron transport (Johnson et al. 2011). The low $\mathrm{pH}$ of the lumen activates $\mathrm{qE}$ by protonating the PsbS protein ( $\mathrm{Li}$ et al. 2000) or indirectly by activating the xanthophyll cycle (Demmig-Adams and Adams 1993). In addition, under limitation of $\mathrm{CO}_{2}$ assimilation, energy from the PET chain can be, in part, redirected to photorespiration $\left(P_{\mathrm{R}}\right)$ (Maurino and Peterhansel 2010). Photorespiration recovers the carbon diverted by the oxygenase activity of Rubisco, transporting and reducing equivalents from the chloroplast, mainly by the activity of malate shuttle. This mechanism would possibly prevent the overreduction of thylakoids and photoinhibition, as occurs in drought stress (Peterhänsel and Maurino 2010). This allocation of reducing equivalents by $P_{\mathrm{R}}$ is also important for nitrate assimilation in $R$. communis under salinity (Lima Neto et al. 2014). Nevertheless, photorespiration produces a great amount of $\mathrm{H}_{2} \mathrm{O}_{2}$ in the peroxisomes by the glycolate oxidase (GO) and in a minor extent $\mathrm{O}_{2}$ radical by peroxisomal superoxide dismutase (SOD) isoforms (Kangasjärvi et al. 2012). Catalase is an important enzyme scavenging the excess $\mathrm{H}_{2} \mathrm{O}_{2}$ in peroxisomes, mainly under high concentrations of $\mathrm{H}_{2} \mathrm{O}_{2}$ (Asada 2006).

The cyclic electron flow (CEF), activated in PSI, results in the generation of a $\mathrm{pH}$ gradient across the thylakoid membrane $(\Delta \mathrm{pH})$, driving ATP synthesis. Therefore, by inducing $\mathrm{qE}$, light harvesting is regulated, without the accumulation of NADPH in chloroplasts (Joliot and Johnson 2011) and possibly dissipating absorbed energy by photosystem I (PSI) (Johnson 2011). CEF-PSI consists in two pathways, PGR5 and PGRL1 proteins dependent, whereas the minor pathway is mediated by NDH complex (Yamori et al. 2016). However, the complex regulation of the CEF in plants exposed to stress is not clearly yet. There is controversy over the contribution and regulation of this process as an effective photoprotective mechanism (Zivcak et al. 2013). 
In view of this, it is pertinent to look critically at tolerance strategies of naturally drought tolerant plants to understand strategies to maintain crop productivity (Ogbaga et al. 2014). The aim of this study was to examine the physiological and biochemical responses of $R$. communis to drought and its capacity of recovery. In particular, we have focused identifying photoprotective mechanisms and antioxidative metabolism responses that could possible give rise to drought tolerance in this species. $R$. communis is a species well adapted to arid and semiarid environments as potential crop for biofuel production (Lima Neto et al. 2015).

\section{Materials and methods}

\section{Plant material and growth conditions}

Seeds of $R$. communis (L.), cultivar BRS 149, were provided by EMBRAPA, Brazil. Seeds were selected by size and weight and germinated in washed sand. Fifteen days after germination, the seedlings were transferred to plastic pots (8 L) with vermiculite and sand (1:1) as substrate. Plants were grown in a greenhouse located in a semiarid region $\left(3^{\circ} 44^{\prime} 38^{\prime \prime} \mathrm{S}\right.$ and $38^{\circ} 34^{\prime} 11^{\prime \prime} \mathrm{W}, 31 \mathrm{~m}$ altitude). The environmental conditions during the experimental period were: average air temperature of $29 / 24{ }^{\circ} \mathrm{C}$ (maximum/ minimum); average air relative humidity of $62 \%$, maximum photosynthetic photon flux density (PPFD) of $1800 \mu \mathrm{mol} \mathrm{m} \mathrm{m}^{-2} \mathrm{~s}^{-1}$, and $12 \mathrm{~h}$-photoperiod. Plants were watered every other day with distilled water, until drainage, and every 3 days with $400 \mathrm{~mL}$ of a half-strength nutrient solution at pH 6.0 (Hoagland and Arnon 1950). For the water deficit treatment, the irrigation of 45-day-old plants was withdrawn for 9 consecutive days. After these periods, a set of plants were harvested (drought) and another group was rewatered for 6 days (recovery). The well-watered plants (daily irrigated to near pot saturation) were used as control during all the experiment. Throughout the experimental period, the leaf gas exchange and chlorophyll $a$ fluorescence were measured every 3 days between 9 and $10 \mathrm{~h}$. On the ninth day of drought and after 7 days of recovery, full-expanded leaves were harvested, immersed in liquid $\mathrm{N}_{2}$, and stored at $-80{ }^{\circ} \mathrm{C}$ until biochemical determinations.

\section{Leaf dry matter, relative water content, water potential, electrolyte leakage, and pigment content}

The leaf fresh matter (FM) of each plant was measured just after harvesting. The leaf relative water content (RWC) was calculated from differences of fresh, turgid, and dry weight in leaf discs, as previously described (Lima Neto et al. 2015). Dry matter (DM) is the dry weight determined after $48 \mathrm{~h}$ in an oven at $75^{\circ} \mathrm{C}$ and the turgid weight was measured after $6 \mathrm{~h}$ of saturation in deionized water at $4{ }^{\circ} \mathrm{C}$ in dark condition. The leaf predawn water potential $\left(\Psi_{\mathrm{w}}\right)$ was evaluated immediately after sampling using the pressure chamber (3000 Scholander PWSC, ICT international, Armidale, AUS) method (Scholander 1960). The electrolyte leakage was assessed as described previously (Lima Neto et al. 2015) and the photosynthetic pigments (chl $a, b$, total, and carotenoids) contents were assessed (Lichtenthaler and Wellburn 1983).

\section{Leaf gas exchange, chlorophyll $\boldsymbol{a}$ fluorescence, and $\mathbf{P 7 0 0}$ redox state measurements}

For the assessment of gas exchange and photochemical parameters, plants were transferred to a growth chamber, with controlled conditions of $29^{\circ} \mathrm{C}$, RH $70 \%$, and PPFD of $700 \mu \mathrm{mol} \mathrm{m} \mathrm{s}^{-2}$. After $1 \mathrm{~h}$ of plant acclimation to these conditions, the measurements were performed in the third full-expanded leaf. The net $\mathrm{CO}_{2}$ assimilation rate $\left(P_{\mathrm{N}}\right)$, stomatal conductance $\left(g_{\mathrm{s}}\right)$, transpiration $(E)$, and intercellular $\mathrm{CO}_{2}$ partial pressure $\left(C_{\mathrm{i}}\right)$ were measured with a portable infrared gas analyzer system, equipped with a LED source (IRGA LI-6400XT, LI-COR, Lincoln, NE, USA). During the measurements, the conditions inside the IRGA chamber were set to PPFD of $1500 \mu \mathrm{mol} \mathrm{m}{ }^{-2} \mathrm{~s}^{-1}$, air $\mathrm{CO}_{2}$ partial pressure of $38 \mathrm{~Pa}$, air vapor pressure deficit of $1.2 \pm 0.5 \mathrm{kPa}$, and air temperature of $28^{\circ} \mathrm{C}$. The amount of blue light was set to $10 \%$ of the PPFD to maximize stomatal aperture (Flexas et al. 2007). Measuring conditions were in accordance with the optimum one's for photosynthesis within the specie (Lima Neto et al. 2015). The $P_{\mathrm{N}}$ responses to changes in PPFD and $\mathrm{CO}_{2}$ concentration were evaluated and fitted according to the models proposed by Lieth and Reynolds (1987) and Sharkey et al. (2007), respectively. From the photosynthetic response curves to PPFD and chloroplastidial $\mathrm{CO}_{2}$ partial pressure $\left(C_{\mathrm{c}}\right)$, we were able to estimate the maximum Rubisco carboxylation rate $\left(V_{\text {cmax }}\right)$, the maximum photosynthetic rate $\left(P_{\mathrm{Nmax}}\right)$, day respiration $\left(R_{\mathrm{d}}\right)$, mesophyll conductance $\left(g_{\mathrm{m}}\right)$, and the maximum rate of photosynthetic electron transport driving RuBP regeneration $\left(J_{\max }\right)$.

In vivo chlorophyll $a$ fluorescence was measured using an LI-6400-40 Leaf Chamber Fluorometer (LI-COR, Lincoln, NE, USA) coupled to the IRGA. The fluorescence measurements were taken using the saturation pulse method (Klughammer and Schreiber 1994) in light and dark-adapted (30 min) leaves. The intensity and duration of the saturation light pulse were $8000 \mu \mathrm{mol} \mathrm{m} \mathrm{m}^{-2} \mathrm{~s}^{-1}$ and $0.7 \mathrm{~s}$, respectively. The measurements of chlorophyll fluorescence in light-adapted samples were taken simultaneously to the measurements of leaf gas exchange, 
under the same chamber conditions. The following parameters were assessed: the maximum quantum efficiency of PSII $\left[F_{\mathrm{v}} / F_{\mathrm{m}}=\left(F_{\mathrm{m}}-F_{\mathrm{o}}\right) / F_{\mathrm{m}}\right]$, the effective quantum efficiency of PSII [ $\left.\phi_{\mathrm{PSII}}=\left(F_{\mathrm{m}}^{\prime}-F_{\mathrm{s}}\right) / F_{\mathrm{m}}^{\prime}\right]$, the nonphotochemical quenching $\left[\mathrm{NPQ}=\left(F_{\mathrm{m}}-F_{\mathrm{m}}^{\prime}\right) / F_{\mathrm{m}}^{\prime}\right]$, and the apparent electron transport rate through the photosystem II $\left[\mathrm{ETR}_{\mathrm{II}}=\left(\phi_{\mathrm{PSII}} \times \mathrm{PPFD} \times 0.5 \times 0.84\right)\right]$. To estimate $\mathrm{ETR}_{\mathrm{II}}, 0.5$ was used as the fraction of excitation energy distributed to PSII, and 0.84 was the fraction of incoming light absorbed by the leaves. The $F_{\mathrm{m}}$ and $F_{\mathrm{o}}$ are the maximum and minimum fluorescence of dark-adapted leaves, respectively; $F_{\mathrm{m}}^{\prime}, F_{\mathrm{o}}^{\prime}$, and $F_{\mathrm{s}}$ are the maximum, the minimum, and the steady-state fluorescence in the light-adapted samples (Maxwell and Johnson 2000). The estimation of the photorespiratory rate $\left(P_{\mathrm{R}}\right)$ was performed according to Bagard et al. (2008), as $P_{\mathrm{R}}=1 / 12\left[\mathrm{ETR}_{\mathrm{II}}-4\left(P_{\mathrm{N}}+R_{\mathrm{d}}\right)\right]$.

The redox state of the PSI was measured using a DUALPAM 100 (Walz, Effeltrich, Germany). The photochemical quantum efficiency of PSI ( $\left.\phi_{\text {PSI }}\right)$ and the electron transport rate through PSI $\left(\mathrm{ETR}_{\mathrm{I}}\right)$ were assessed. The estimation of the cyclic electron flow (CEF) was estimated by the $\mathrm{ETR}_{\mathrm{I}} /$ ETR $_{\text {II }}$ ratio (Yamori et al. 2011). Photochemical activity of PSI was measured under the same conditions described previously for measurements of PSII activity and leaf gas exchange.

\section{Lipid peroxidation and hydrogen peroxide content}

The lipid peroxidation was assessed evaluating the thiobarbituric acid reactive substances (TBARS) in accordance to Cakmak and Horst (1991), with modifications described by Bonifacio et al. (2011). Readings were taken by the difference in absorption of 660 and $532 \mathrm{~nm}$. The concentration of TBARS was assessed by the absorption coefficient of $155 \mathrm{mM}^{-1} \mathrm{~cm}^{-1}$ and the results expressed as nmol MDA-TBA g ${ }^{-1}$ FM. Hydrogen peroxide content was measured by the titanium tetrachloride $\left(\mathrm{TiCl}_{4}\right)$ method according to Brennan and Frenkel (1977). Fresh leaf discs were macerated with liquid $\mathrm{N}_{2}$ containing $5 \%(\mathrm{w} / \mathrm{v})$ TCA and centrifuged at $12,000 \mathrm{~g}\left(4^{\circ} \mathrm{C}\right)$, and the supernatant was used for the $\mathrm{H}_{2} \mathrm{O}_{2}$ determination. The measurement was performed after reaction of $\mathrm{TiCl}_{4}$ with hydrogen peroxide and the $\mathrm{H}_{2} \mathrm{O}_{2}$ concentration was calculated from a $\mathrm{H}_{2} \mathrm{O}_{2}$ standard curve (Sigma). Readings were taken at $415 \mathrm{~nm}$ with a spectrophotometer and expressed as $\mu \mathrm{mol} \mathrm{H}_{2} \mathrm{O}_{2} \mathrm{~g}^{-1}$ FM.

\section{Preparation of leaf extract and enzyme activity assays}

For preparation of leaf extracts, fresh leaf samples were grounded in liquid $\mathrm{N}_{2}$ with a mortar and pestle and extracted with cold $100 \mathrm{mM}$ Tris- $\mathrm{HCl}$ buffer, $\mathrm{pH} 8$,
$0.1 \mathrm{mM}$ EDTA, $1 \mathrm{mM}$ ascorbic acid, 20\% glycerol, $3 \%$ PEG-6000 and $30 \mathrm{mM}$ DTT. The enzymatic extract was stored at $-20{ }^{\circ} \mathrm{C}$ until the determinations.

Total ascorbate peroxidase (APX) activity (EC 1.11.1. 11) was measured by the ascorbate oxidation following the decreases in absorbance at $290 \mathrm{~nm}$ (Nakano and Asada 1981), with minor modifications described in Bonifacio et al. (2011). The activity was assayed with $0.5 \mathrm{mM}$ ascorbate and $0.1 \mathrm{mM}$ EDTA dissolved in $100 \mathrm{mM} \mathrm{K}$ phosphate buffer $\mathrm{pH} 7.0$ and leaf extract. The reaction started by adding $30 \mathrm{mM} \mathrm{H} \mathrm{O}_{2}$. The enzyme activity was measured by the decrease in absorbance at $290 \mathrm{~nm}$ and $25^{\circ}$ $\mathrm{C}$ over a $300 \mathrm{~s}$ period, being expressed as $\mu \mathrm{mol}$ ascorbate $(\mathrm{mg} \text { protein } \mathrm{min})^{-1}$.

Total superoxide dismutase (SOD) activity (EC 1.15.1.1) was measured by the inhibition of the blue formazan by the nitroblue tretazolium chloride (NBT) photoreduction. The SOD activity was measured with the leaf extract in a mixture of $50 \mathrm{mM}$ potassium phosphate buffer (pH 7.8), $0.1 \mathrm{mM}$ EDTA, $13 \mathrm{mM}$ L-methionine, $2 \mu \mathrm{M}$ riboflavin, and $75 \mu \mathrm{m} p$-nitroblue tetrazolium chloride (NBT) in the dark. The reaction was exposed to illumination ( $30 \mathrm{~W}$ fluorescent lamp) at $25{ }^{\circ} \mathrm{C}$ for $6 \mathrm{~min}$. The absorbance was measured at $540 \mathrm{~nm}$ (Giannopolotis and Ries 1977). A SOD activity unit (U) was defined as the amount of enzyme able to inhibit 50\% of the NBT photoreduction. The activity was expressed as $\mathrm{U}$ (mg protein $\min )^{-1}$.

Total catalase (CAT) activity (EC 1.11.1.6) was assessed by the oxidation of $\mathrm{H}_{2} \mathrm{O}_{2}$ at $240 \mathrm{~nm}$. CAT activity was determined after the reaction of the enzymatic leaf extract in the presence of $50 \mathrm{mM}$ potassium phosphate buffer $(\mathrm{pH}$ 7) with $20 \mathrm{mM} \mathrm{H} \mathrm{H}_{2} \mathrm{O}_{2}$. The absorbance at $240 \mathrm{~nm}$ was measured over $300 \mathrm{~s}$ (Havir and McHale 1987), and the catalase activity was calculated with the molar extinction coefficient of $\mathrm{H}_{2} \mathrm{O}_{2}\left(36 \mathrm{mM}^{-1} \mathrm{~cm}^{-1}\right)$ and expressed as $\mu \mathrm{mol}$ $\mathrm{H}_{2} \mathrm{O}_{2}$ (mg protein min $)^{-1}$.

The glycolate oxidase (GO) activity (EC 1.1.3.15) was assayed by measuring the rate of glyoxylate-phenylhydrazone complex formation at $324 \mathrm{~nm}$ (Baker and Tolbert 1966). The GO activity was estimated from the molar extinction coefficient of the glyoxylate-phenylhydrazona complex $\left(17 \mathrm{mM}^{-1} \mathrm{~cm}^{-1}\right)$. The results were expressed as $\mu$ mol glyoxylate (mg protein $\min )^{-1}$.

Rubisco (EC: 4.1.1.39) activity was measured following the oxidation rate of NADH at $340 \mathrm{~nm}$ (Reid et al. 1997). The initial Rubisco activity was assessed from the extract added with $900 \mu \mathrm{L}$ of the assay mixture, and the reaction was initiated with the addition of $0.5 \mathrm{mM}$ RuBP. Total activity was measured when the reaction was started after 15 min of incubation of the mixture reaction in the absence of RuBP. Thereafter, $0.5 \mathrm{mM}$ RuBP was added, and the total activity was measured following the oxidation NADH 
at $340 \mathrm{~nm}$. Both activities were expressed as $\mu \mathrm{mol} \mathrm{CO} \mathrm{Cm}^{-2}$ $\mathrm{s}^{-1}$. The Rubisco activation state was calculated by the initial activity/total activity ratio and expressed as percentage (\%).

\section{Statistical and experimental design}

The experiments were arranged in a completely randomized design with five independent replicates, each one represented by an individual plant per pot. Data were analyzed using ANOVA and the means were compared using the Tukey's test $(P<0.05)$.

\section{Results}

\section{Growth, water relations, and photosynthetic pigments content}

Drought decreased the relative water content (RWC) and the water potential $\left(\Psi_{\mathrm{w}}\right)$ in $R$. communis leaves (Table 1). After 6 days of rehydration (recovery), the RWC reached the control level, whereas the $\Psi_{\mathrm{w}}$ was lower than control (Table 1). The electrolyte leakage, an indicator of the cell membrane integrity, was statically significant increased by two-fold in leaves exposed to drought. However, this parameter was completely recovered to control levels after 6 days of rehydration. The leaf dry matter was decreased by drought with a slightly increase after the recovery period (Table 1). The total chlorophyll content was decreased under drought and after the recovery was increased to higher levels compared with control. However, the chlorophyll $a / b$ ratio was statically significant decreased by drought, with full recovery to control levels after the rehydration (Table 1). The total carotenoid content

Table 1 Leaf relative water content (RWC), leaf water potential $\left(\Psi_{\mathrm{w}}\right)$, electrolyte leakage, leaf dry matter $(\mathrm{DM})$, and photosynthetic pigments content in Ricinus communis plants under well-watered conditions for 15 days (control), exposed to 9 days of water withholding (drought) and exposed to 9 days of drought plus 6 days of rehydration (recovery)

\begin{tabular}{llll}
\hline Traits & Control & Drought & Recovery \\
\hline RWC (\%) & $82.2 \mathrm{a}$ & $65.8 \mathrm{~b}$ & $79.2 \mathrm{a}$ \\
$\Psi_{\mathrm{w}}(\mathrm{MPa})$ & $-0.71 \mathrm{c}$ & $-2.34 \mathrm{a}$ & $-1.12 \mathrm{~b}$ \\
Electrolyte leakage $(\%)$ & $20.3 \mathrm{~b}$ & $46.5 \mathrm{a}$ & $21.15 \mathrm{~b}$ \\
Leaf DM $\left(\mathrm{g} \mathrm{plant}^{-1}\right)$ & $8.34 \mathrm{a}$ & $4.36 \mathrm{~b}$ & $5.26 \mathrm{~b}$ \\
Total chlorophyll $\left(\mathrm{mg} \mathrm{g}^{-1} \mathrm{DM}\right)$ & $6.02 \mathrm{~b}$ & $5.63 \mathrm{c}$ & $6.78 \mathrm{a}$ \\
Chlorophyll $\mathrm{a} / \mathrm{b}_{\text {Carotenoids }\left(\mathrm{mg} \mathrm{g}^{-1} \mathrm{DM}\right)}$ & $2.1 \mathrm{a}$ & $1.1 \mathrm{~b}$ & $1.89 \mathrm{a}$ \\
\hline
\end{tabular}

$\overline{\text { Different letters represent significant difference between treatments }}$ by Tukey's test $(P<0.05)$ increased in leaves of $R$. communis under drought and this parameter was maintained after the recovery treatment (Table 1).

Gas exchange, fluorescence of chlorophyll,
photorespiration, and $\mathrm{P}^{+} 00^{+}$redox state

Net photosynthesis $\left(P_{\mathrm{N}}\right)$ was strongly decreased in $R$. communis plants exposed to drought, but after 6 days of rehydration, $P_{\mathrm{N}}$ was increased, but this increase was not able to reach control levels (Fig. 1a). Stomatal conductance $\left(g_{\mathrm{s}}\right)$ and transpiration $(E)$ followed the same trend of $P_{\mathrm{N}}$. However, these parameters were completely recovered after 6 days of rehydration (Fig. 1b, c). The internal partial pressure of $\mathrm{CO}_{2}\left(C_{\mathrm{i}}\right)$ was decreased during drought, and as $g_{\mathrm{s}}$ and $E$, it was completed recovered after rehydration (Fig. 1d). Regarding the $P_{\mathrm{N}}-$ PPFD and $P_{\mathrm{N}}-C_{\mathrm{c}}$ response curve parameters, it was shown that $R$. communis presented metabolic limitation of photosynthesis after 9 days of continuous drought, as showed by the decreases in the maximum photosynthetic rate $\left(P_{\mathrm{Nmax}}\right)$, the maximum carboxylation rate of Rubisco $\left(V_{\mathrm{cmax}}\right)$, and the maximum photosynthetic electron transport rate driving RuBP regeneration $\left(J_{\max }\right)$. After the recovery treatment, these parameters were not completely recovered (Table 2). The mesophyll conductance $\left(g_{\mathrm{m}}\right)$, estimated from the $P_{\mathrm{N}}-C_{\mathrm{c}}$ modelling, was decreased after drought, and after the recovery treatment $g_{\mathrm{m}}$ was higher than control (Table 2).

It was possible that $R$. communis displayed both stomatal and metabolic limitation of photosynthesis during the drought treatment. In addition, the rehydration period could not be able to completely recover the metabolic limitation of $P_{\mathrm{N}}$. To complement these results, we performed an in vitro activity of Rubisco (Fig. 2). The initial activity of Rubisco decreased by $62 \%$ in plants exposed to drought and it was not completely recovered, corroborating the previous data. In contrast, the activation state of Rubisco was maintained at control level for drought as well as for the recovery treatment (Fig. 2).

Ricinus communis plants displayed photoinhibition after 6 days of drought, as showed by decreases in $F_{\mathrm{v}} / F_{\mathrm{m}}$ (Fig. 3a). In contrast, the effective yield of PSII ( $\left.\phi_{\mathrm{PSII}}\right)$ and the electron transport rate at PSII (ETRII) were decreased from the third day of drought, and these parameters were completely recovered after the rehydration (Fig. 3b). It is plausible to note that this efficient modulation of the electron transport chain at PSII under drought could be modulated by the increase in the non-photochemical quenching, which, in some extent, was maintained after the recovery period (Fig. 3d). The effective quantum yield of PSI $\left(\phi_{\mathrm{PSI}}\right)$ and the electron transport rate at PSI (ETRI) were decreased by drought, and these parameters presented complete recover after the rehydration period (Fig. 4a). 


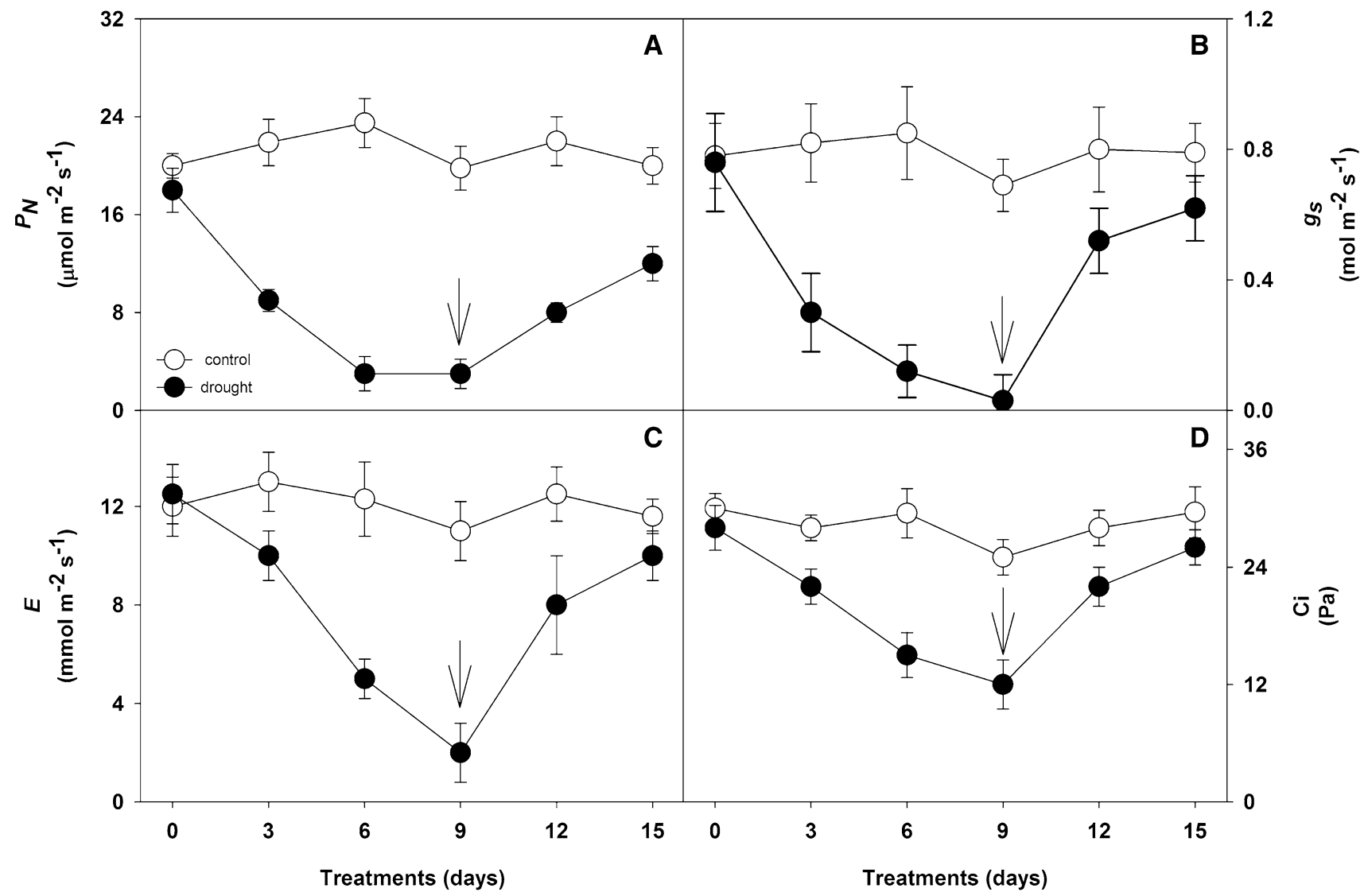

Fig. 1 Leaf gas exchange parameters in $R$. communis plants under well-watered conditions for 15 days (control), exposed to 9 days of water withholding (drought) and exposed to 9 days of drought plus 6 days of rehydration (recovery). Photosynthesis (a), stomatal

Table 2 Photosynthetic parameters derived from $P_{\mathrm{N}}-$ PPFD and $P_{\mathrm{N}}-C_{\mathrm{c}}$ curves and Rubisco activity in $R$. communis under wellwatered conditions for 15 days (control), exposed to 9 days of water withholding (drought) and exposed to 9 days of drought plus 6 days of rehydration (recovery)

\begin{tabular}{llll}
\hline Traits & Control & Drought & Recovery \\
\hline$P_{\text {Nmax }}\left(\mu \mathrm{mol} \mathrm{m} \mathrm{m}^{-1}\right)$ & $34.2 \mathrm{a}$ & $8.18 \mathrm{c}$ & $22.5 \mathrm{~b}$ \\
$V_{\mathrm{cmax}}\left(\mu \mathrm{mol} \mathrm{m} \mathrm{s}^{-1}\right)$ & $123 \mathrm{a}$ & $21 \mathrm{c}$ & $86 \mathrm{~b}$ \\
$J_{\max }\left(\mu \mathrm{mol} \mathrm{m} \mathrm{s}^{-1}\right)$ & $131 \mathrm{a}$ & $43 \mathrm{c}$ & $112 \mathrm{~b}$ \\
$g_{\mathrm{m}}\left(\mathrm{mol} \mathrm{m}^{-2} \mathrm{~s}^{-1}\right)$ & $0.075 \mathrm{~b}$ & $0.063 \mathrm{c}$ & $0.082 \mathrm{a}$ \\
\hline
\end{tabular}

Different letters represent significant difference between treatments by Tukey's test $(P<0.05)$

$P_{N \max }$ maximum photosynthetic rate, $V_{c \max }$ maximum carboxylation rate of Rubisco, $J_{\max }$ maximum photosynthetic electron transport rate driving RuBP regeneration, $g_{m}$ mesophyll conductance

Interesting to note that the relative decrease of ETRII was higher than the relative decrease of ETRI in plants exposed to drought, suggesting an increment of the cyclic electron flow (CEF) around PSI. To estimate the CEF, we calculate the ETRI/ETRII ratio (Yamori et al. 2011). This ratio clearly shows that the CEF was induced in plants exposed conductance (b), transpiration (c), and $\mathrm{CO}_{2}$ internal partial pressure (d). Down arrow represents rehydration to near pot capacity. Data are the means of five replicates \pm standard deviation (SD)

to drought and decreased during the recovery treatment (Fig. 4c).

Drought increased the estimated photorespiration $\left(P_{\mathrm{R}}\right)$ approximately by two-fold (Fig. 5a). Accordingly, there was a large increase in GO and CAT activities in $R$. communis under drought (Fig. 5b, c). These activities were maintained at higher levels after the recovery, compared with control. The glycolate oxidation to glyoxylate in higher plants is catalyzed by GO. The enzyme is present in the peroxisome and performs an essential step in $P_{\mathrm{R}}$. Thus, GO activity is commonly used as a biomarker of $P_{\mathrm{R}}$ (Zelitch et al. 2009). CAT is located in the peroxisomes and virtually absent from chloroplasts, scavenging $\mathrm{H}_{2} \mathrm{O}_{2}$ by catalyzing its decomposition into $\mathrm{O}_{2}$ and $\mathrm{H}_{2} \mathrm{O}$ (Foyer et al. 2009). Therefore, CAT activity could be assessed as an indirect measure of $P_{\mathrm{R}}$.

\section{Lipid peroxidation, $\mathrm{H}_{2} \mathrm{O}_{2}$ content, and antioxidative enzymes}

Drought increased the content of TBARS and $\mathrm{H}_{2} \mathrm{O}_{2}$ in $R$. communis leaves (Table 3). However, these parameters 


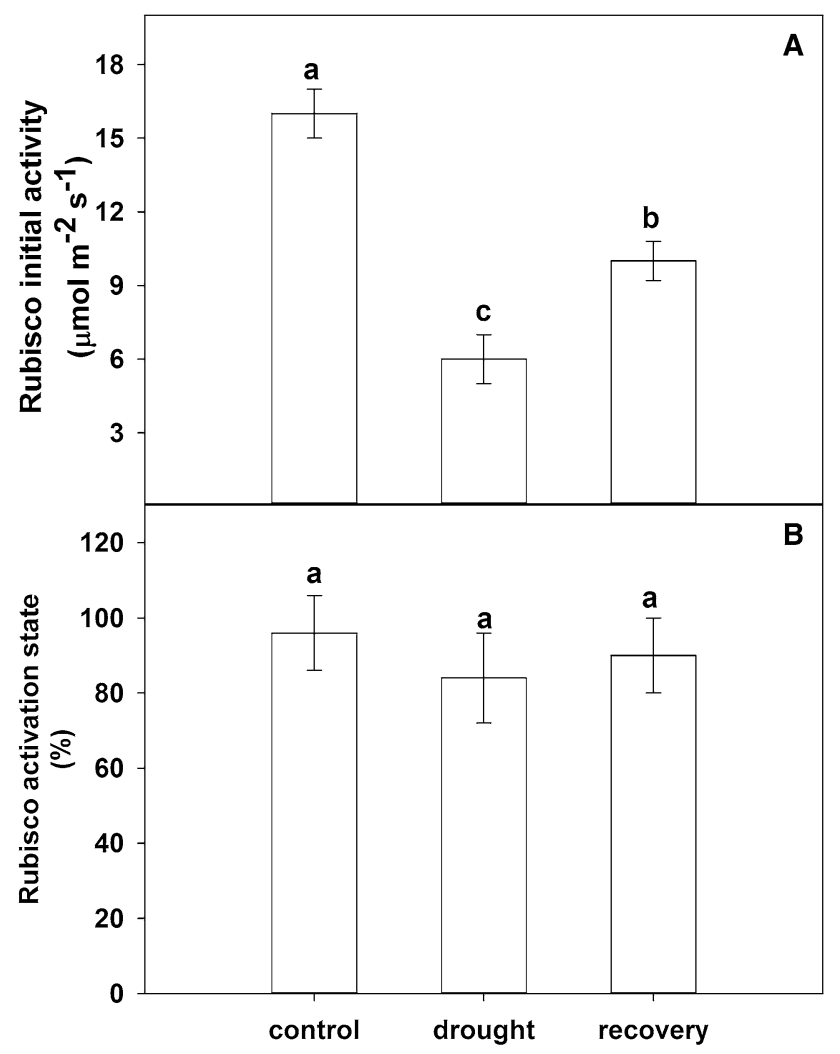

Fig. 2 Rubisco initial activity (a) and Rubisco activation state (b) in $R$. communis plants under well-watered conditions for 15 days (control), exposed to 9 days of water withholding (drought) and exposed to 9 days of drought plus 6 days of rehydration (recovery). Data are the means of five replicates \pm standard deviation (SD) and different letters represent a significant difference between treatments by Tukey's test $(P<0.05)$

were maintained at higher levels, compared with control, after the recovery period. Probably, the regulation of the photosynthetic electron transport chain and the photoprotective mechanisms were not able to maintain the $\mathrm{H}_{2} \mathrm{O}_{2}$ at control level, leading to lipid peroxidation and membrane damage. Nevertheless, the activities of APX and SOD, important antioxidative enzymes, were increased under drought, and these enzymes activities were maintained at higher levels after the recovery treatment (Table 3).

\section{Discussion}

The better understanding of physiological traits triggered by drought tolerant plants is crucial to crop yield, so that these can be transferred into new varieties. In this study, $R$. communis plants, an oilseed species, commonly used to biofuel production in arid and semiarid were studied. $R$. communis is a Euphorbiaceae described as drought tolerant triggering osmotic adjustment to avoid the harmful effects of drought (Babita et al. 2010). In addition, it was shown that $R$. communis has a high photosynthetic capacity under high humidity and a pronounced sensitivity to high water vapor pressure deficit (VPD) (Dai et al. 1992), displaying high transpiration rate and stomatal conductance (Barbour and Buckley 2007).

In the current study, we show that drought impacts some important physiological traits in $R$. communis, but after rewatering, this species could continue growth and development. Drought induced decreases in leaf dry matter, relative water content (RWC), water potential, and membrane damage in $R$. communis leaves, with decreases in chlorophyll content and increases in carotenoids concentration. However, 6 days of rehydration could recover the water status and membrane integrity in this species (Table 1). These data clearly show that $R$. communis has a potential to recover growth after short drought period. Interesting to note that after the recovery treatment, $R$. communis leaves presented higher content of total chlorophyll and carotenoids compared with control. Possibly, these increases in photosynthetic pigments were important to avoid the excess energy (Ogbaga et al. 2014) produced by the stomatal closure during drought leading to lower $\mathrm{CO}_{2}$ assimilation rate (Fig. 1). Commonly, changes in chlorophyll concentration and composition are related with a reorganization of the photosynthetic apparatus in response to drought (Ogbaga et al. 2014). In addition, increases in carotenoid content are commonly reported as a photoprotector mechanism acting on singlet oxygen quenching within the reaction center complex (Ballottari et al. 2014; Finazzi et al. 2004).

$R$. communis plants displayed stomatal limitation of photosynthesis during drought as shown by decreases in $g_{\mathrm{s}}$, $E$, and $C_{\mathrm{i}}$ (Fig. 1). However, the stomatal control was efficient in $R$. communis recovery after rehydration (Fig. 1), showing increases in $g_{\mathrm{s}}, E$, and accumulation in $C_{\mathrm{i}}$. It was previously shown that $R$. communis has high photosynthetic capacity under low vapor pressure deficit (VPD) conditions which was comparable to maize (Dai et al. 1992). In contrast, under drought, this species maintains a significant level of transpiration (Fig. 1c), resulting in a low water use efficiency which is in accordance with Barbour and Buckley (2007) and Babita et al. (2010). Nevertheless, after rehydration, the $\mathrm{CO}_{2}$ assimilation rate was not completely recovered (Fig. 1a), possibly due to metabolic limitation of photosynthesis, as showed by decreases in $V_{\text {cmax }}, J_{\max }$ (Table 2), in vitro Rubisco activity and increases in $C_{\mathrm{i}}$ (Fig. 2). It was previously demonstrated that increases in $C_{\mathrm{i}}$ at moderate-to-severe drought are closely related to metabolic impairment in photosynthesis, reflecting the impairment on Rubisco activity and regeneration of RuBP content (Flexas 2002). As stomata close, $C_{\mathrm{i}}$ primarily declines with the stress and then increases as drought becomes more severe (Chaves et al. 2009). 


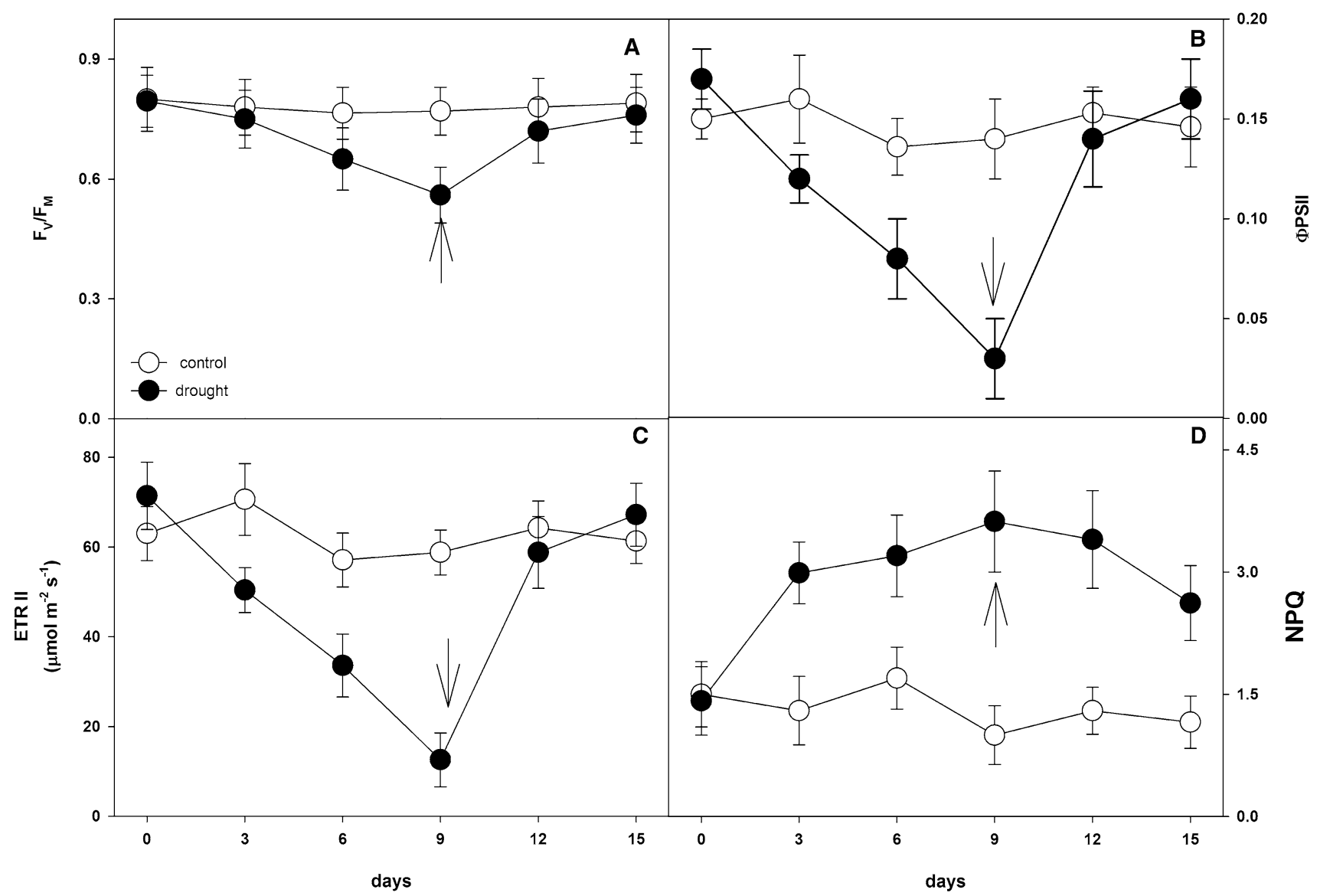

Fig. 3 Potential quantum yield of PSII (a), effective quantum yield of PSII (b), electron transport rate at PSII (c), and non-photochemical quenching in $R$. communis plants under well-watered conditions for 15 days (control), exposed to 9 days of water withholding (drought)

However, the effects of drought on the mechanisms that control Rubisco activity are unclear (Galmés et al. 2011).

Interesting to note that the activation state of Rubisco was not affected by drought under the experimental conditions applied (Fig. 2b). Rubisco activation by reaction with $\mathrm{CO}_{2}$ resulting in the carbamylation of a lysyl residue in its active site is crucial to the activity of this enzyme (Sage et al. 2009). Drought through changes in stomatal and mesophyll conductance induces a decrease in $\mathrm{CO}_{2}$ concentration in leaves and in the amount of activator $\mathrm{CO}_{2}$ bound by carbamylation to Rubisco (Ristic et al. 2009). Galmés et al. (2011) show that the activation state of Rubisco is maintained under mild-to-moderate water stress, depending on the species and declining under severe water stress, which is in accordance with our data.

Inhibition of $\mathrm{CO}_{2}$ assimilation by drought resulted in down-regulation of PSII yield and ETRII, with increases in NPQ (Fig. 3b-d). NPQ is an important photoprotective mechanism related with the dissipation of excess energy as heat $(\mathrm{qE})$ produced by the decreases in $\mathrm{CO}_{2}$ assimilation (Ruban 2016). In addition, decreases in $\phi_{\text {PSI }}$ and ETRI and exposed to 9 days of drought plus 6 days of rehydration (recovery). Arrows represent rehydration to near pot capacity. Data are the means of five replicates \pm standard deviation (SD)

(Fig. 4) were lower compared with PSII (Fig. 3), probably by increases in the CEF (Fig. 4). The cyclic electron flow is important to sustain a $\Delta \mathrm{pH}$ across the thylakoids membranes maintaining NPQ (Zivcak et al. 2014) and possibly preventing photoinhibition of PSII (Goh et al. 2011) and PSI. Overreduction of both photosystems can lead to ROS production (Joliot and Johnson 2011; Sejima et al. 2016; Takagi et al. 2016). It is interesting to note that after the recovery period, the NPQ was maintained at higher levels compared with control (Fig. 3d) with a concomitant decrease in CEF (Fig. 4c). This could be plausible due to increases in the linear electron flow (LEF) and increases in $\mathrm{CO}_{2}$ assimilation after recovery, sustaining the $\Delta \mathrm{pH}$ necessary for the NPQ development (Johnson 2011). In addition to the $\mathrm{CEF}$, an $\mathrm{NAD}(\mathrm{P}) \mathrm{H}$ dehydrogenase (NDH) and plastid terminal oxidase (PTOX) could be involved in the chlororespiratory pathway, alleviating the electron pressure on PSI acceptors by recycling electrons to the PQ and ultimately to PTOX (Rumeau et al. 2007). Chlororespiration helps avoiding the overreduction of the electron acceptors of PSI removing ROS and protecting PSI 


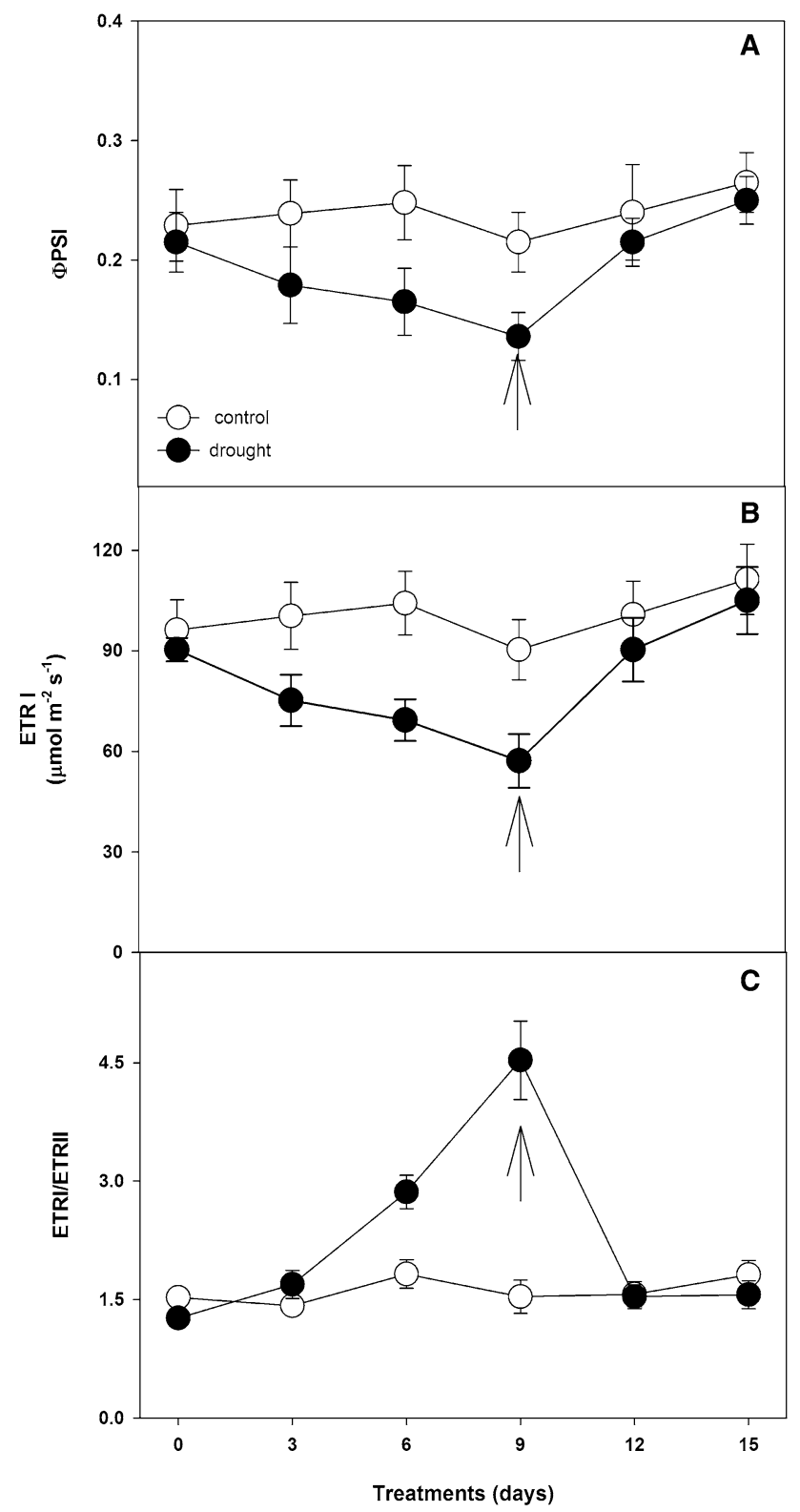

Fig. 4 Effective quantum yield of PSI (a), electron transport rate at PSI (b), and ETRI/ETRII ratio (c) in $R$. communis plants under wellwatered conditions for 15 days (control), exposed to 9 days of water withholding (drought) and exposed to 9 days of drought plus 6 days of rehydration (recovery). Arrows represent rehydration to near pot capacity. Data are the means of five replicates \pm standard deviation (SD)

(Saroussi et al. 2016). However, due to the low abundance of the complex, NDH-mediated electron flows bioenergetically insignificant to ATP production (Joliot and Joliot 2005).

In addition, we show that photorespiration $\left(P_{\mathrm{R}}\right)$ could be an important photoprotective mechanism in $R$. communis under drought (Fig. 5). Drought induced increases in $P_{\mathrm{R}}$, and even after the recovery treatment, $P_{\mathrm{R}}$ were at higher level compared with control. Photorespiration is difficult to

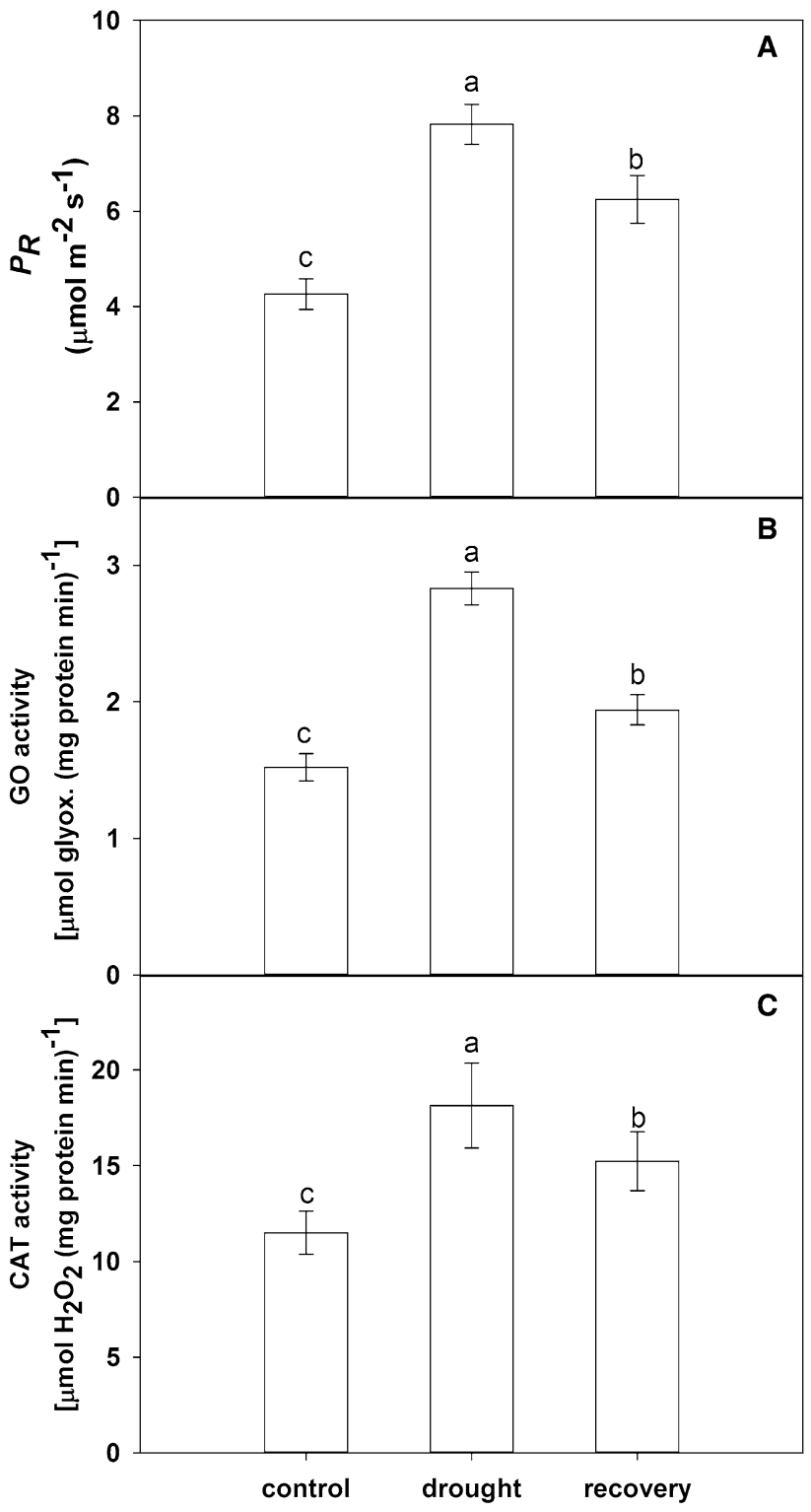

Fig. 5 Estimated photorespiration (a), glycolate oxidase activity (b), and catalase activity (c) in $R$. communis plants under well-watered conditions for 15 days (control), exposed to 9 days of water withholding (drought) and exposed to 9 days of drought plus 6 days of rehydration (recovery). Data are the means of five replicates $\pm \mathrm{s}$ tandard deviation (SD) and different letters represent significant difference between treatments by Tukey's test $(P<0.05)$

be measured (Busch 2013). Nevertheless, we performed GO and CAT activities to corroborate the estimated $P_{\mathrm{R}}$ from fluorescence and gas exchange measurements (Fig. $5 \mathrm{~b}, \mathrm{c}) . P_{\mathrm{R}}$ has the potential to sustain photons in a non-assimilatory pathway, protecting the photosynthetic apparatus against photoinhibition (Peterhänsel and Maurino 2010). In addition, $P_{\mathrm{R}}$ is very important in biochemical recycling, particularly to $\mathrm{N}$-compounds under restrictive metabolic conditions such as drought consuming NADH and reduced ferredoxin (Kangasjärvi et al. 2012). Recently, 
Table 3 Lipid peroxidation (TBARS), $\mathrm{H}_{2} \mathrm{O}_{2}$ concentration, APX, and SOD activities in R. communis under well-watered conditions for 15 days (control), exposed to 9 days of water withholding (drought) and exposed to 9 days of drought plus 6 days of rehydration (recovery)

\begin{tabular}{|c|c|c|c|}
\hline Traits & Control & Drought & Recovery \\
\hline 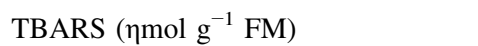 & $38.3 \mathrm{c}$ & $95.26 \mathrm{a}$ & $56.2 \mathrm{~b}$ \\
\hline $\mathrm{H}_{2} \mathrm{O}_{2}\left(\mu \mathrm{mol} \mathrm{g}{ }^{-1} \mathrm{FM}\right)$ & $10.25 \mathrm{c}$ & $21.36 \mathrm{a}$ & $15.22 b$ \\
\hline APX $\left.[\mu \mathrm{mol} \text { AsA (mg protein min) })^{-1}\right]$ & $0.61 \mathrm{c}$ & $1.14 \mathrm{a}$ & $0.82 \mathrm{~b}$ \\
\hline SOD $\left[\mathrm{U}(\mathrm{mg} \text { protein } \min )^{-1}\right]$ & $1.56 \mathrm{c}$ & $3.25 \mathrm{a}$ & $2.52 \mathrm{~b}$ \\
\hline
\end{tabular}

Different letters represent significant difference between treatments by Tukey's test $(P<0.05)$

photorespiration was described as an important mechanism providing the CEF to operate for the redox-regulation of P700 in sunflowers leaves (Takagi et al. 2016), preventing PSI photoinhibition and reducing ROS burst at PSI level.

The enzymatic ROS scavenging system was induced in R. communis plants under drought (Table 3; Fig. 5). The activities of APX, SOD, and CAT, important antioxidative enzymes, were increased by drought, and were maintained in higher levels compared to control after the rehydration treatment. Altogether, the data presented show that $R$. communis trigger diverse photoprotective mechanisms to maintain the integrity of the photochemical apparatus, preventing the harmful damages of the excess energy in the thylakoids produced by drought. An efficient stomatal control in accordance with increases in NPQ, CEF, and $P_{\mathrm{R}}$ is important to drought acclimation in this species. In addition, antioxidative enzymes are responsive to drought, scavenging the excess of ROS produced by the overreduced PET chain (Foyer et al. 2012).

Author contribution statement MCLN and JAGS designed the experiments. MCLN, JVAC, and JRC performed the experiments. MCLN, JAGS, and JRC wrote the manuscript. All authors contributed have seen and approved the manuscript.

Acknowledgements We are grateful to CNPq (Project 445842/20148) and INCTsal-CNPQ/MCTi for financial support and EMPRABACotton by kindly provide the seeds.

\section{Compliance with ethical standards}

Conflict of interest The authors declare that they have no conflict of interest.

\section{References}

Asada K (2006) Production and scavenging of reactive oxygen species in Chloroplasts and their functions. Plant Physiol 141:391-396. doi:10.1104/pp.106.082040

Babita M, Maheswari M, Rao LM, Shanker AK, Rao DG (2010) Osmotic adjustment, drought tolerance and yield in castor (Ricinus communis L.) hybrids. Environ Exp Bot 69:243-249. doi:10.1016/j.envexpbot.2010.05.006
Bagard M, Le Thiec D, Delacote E, Hasenfratz-Sauder M-P, Banvoy J, Gérard J, Dizengremel P, Jolivet Y (2008) Ozone-induced changes in photosynthesis and photorespiration of hybrid poplar in relation to the developmental stage of the leaves. Physiol Plant 134:559-574. doi:10.1111/j.1399-3054.2008.01160.x

Baker AL, Tolbert NE (1966) Glycolate oxidase (ferredoxincontaining form). Methods Enzymol 9:339-340

Ballottari M, Alcocer MJP, D'Andrea C, Viola D, Ahn TK, Petrozza A, Polli D, Fleming GR, Cerullo G, Bassi R (2014) Regulation of photosystem I light harvesting by zeaxanthin. Proc Natl Acad Sci USA 111:E2431-E2438. doi:10.1073/pnas.1404377111

Barbour MM, Buckley TN (2007) The stomatal response to evaporative demand persists at night in Ricinus communis plants with high nocturnal conductance. Plant Cell Environ 30:711-721. doi:10.1111/j.1365-3040.2007.01658.x

Blokhina O, Virolainen E, Fagerstedt KV (2003) Antioxidants, oxidative damage and oxygen deprivation stress: a review. Ann Bot. doi:10.1093/aob/mcf118

Bonifacio A, Martins MO, Ribeiro CW, Fontenele AV, Carvalho FEL, Margis-Pinheiro M, Silveira JA (2011) Role of peroxidases in the compensation of cytosolic ascorbate peroxidase knockdown in rice plants under abiotic stress. Plant Cell Environ. doi:10.1111/j.1365-3040.2011.02366.x

Brennan T, Frenkel C (1977) Involvement of hydrogen peroxide in the regulation of senescence in pear. Plant Physiol 59:411-416. doi:10.1104/pp.59.3.411

Busch FA (2013) Current methods for estimating the rate of photorespiration in leaves. Plant Biol (Stuttg) 15:648-655. doi:10.1111/j.1438-8677.2012.00694.x

Cakmak I, Horst WJ (1991) Effect of aluminium on lipid peroxidation, superoxide dismutase, catalase, and peroxidase activities in root tips of soybean (Glycine max). Physiol Plant 83:463-468. doi:10.1111/j.1399-3054.1991.tb00121.x

Carvalho FEL, Ware MA, Ruban AV (2015) Quantifying the dynamics of light tolerance in Arabidopsis plants during ontogenesis. Plant Cell Environ 38:2603-2617. doi:10.1111/ pce. 12574

Chaves MM, Flexas J, Pinheiro C (2009) Photosynthesis under drought and salt stress: regulation mechanisms from whole plant to cell. Ann Bot 103:551-560. doi:10.1093/aob/mcn125

Dai Z, Edwards GE, Ku MSB (1992) Control of photosynthesis and stomatal conductance in Ricinus communis L. (Castor Bean) by leaf to air vapor pressure deficit. Plant Physiol 99:1426-1434. doi:10.1104/pp.99.4.1426

Demmig-Adams B, Adams WW (1993) The xanthophyll cycle, protein turnover, and the high light tolerance of sun-acclimated leaves. Plant Physiol 103:1413-1420

Finazzi G, Johnson GN, Dallosto L, Dallosto L, Joliot P, Wollman F-A, Bassi R (2004) A zeaxanthin-independent nonphotochemical quenching mechanism localized in the photosystem II core complex. Proc Natl Acad Sci USA 101:12375-12380. doi:10. 1073/pnas.0404798101 
Flexas J (2002) Drought-inhibition of photosynthesis in C3 plants: stomatal and non-stomatal limitations revisited. Ann Bot 89:183-189. doi:10.1093/aob/mcf027

Flexas J, Escalona JM, Medrano H (1999) Water stress induces different levels of photosynthesis and electron transport rate regulation in grapevines. Plant Cell Environ 22:39-48. doi:10. 1046/j.1365-3040.1999.00371.x

Flexas J, Diaz-Espejo A, Galmés J, Kaldenhoff R, Medrano H, RibasCarbo M (2007) Rapid variations of mesophyll conductance in response to changes in $\mathrm{CO}_{2}$ concentration around leaves. Plant Cell Environ 30:1284-1298. doi:10.1111/j.1365-3040.2007. 01700.x

Flexas J, Barbour MM, Brendel O, Cabrera HM, Carriquí M, DíazEspejo A, Douthe C, Dreyer E, Ferrio JP, Gago J, Gallé A, Galmés J, Kodama N, Medrano H, Niinemets Ü, Peguero-Pina JJ, Pou A, Ribas-Carbó M, Tomás M, Tosens T, Warren CR (2012) Mesophyll diffusion conductance to $\mathrm{CO}_{2}$ : an unappreciated central player in photosynthesis. Plant Sci 193-194:70-84. doi:10.1016/j.plantsci.2012.05.009

Foyer CH, Bloom AJ, Queval G, Noctor G (2009) Photorespiratory metabolism: genes, mutants, energetics, and redox signaling. Annu Rev Plant Biol 60:455-484. doi:10.1146/annurev.arplant. 043008.091948

Foyer CH, Neukermans J, Queval G, Noctor G, Harbinson J (2012) Photosynthetic control of electron transport and the regulation of gene expression. J Exp Bot 63:1637-1661. doi:10.1093/jxb/ ers013

Galmés J, Ribas-Carbó M, Medrano H, Flexas J (2011) Rubisco activity in Mediterranean species is regulated by the chloroplastic $\mathrm{CO}_{2}$ concentration under water stress. J Exp Bot 62:653-665. doi:10.1093/jxb/erq303

Giannopolotis CN, Ries SK (1977) Superoxide dismutases: occurrence in higher plants. Plant Physiol 59:309-314

Goh C-H, Ko S-M, Koh S, Kim Y-J, Bae H-J (2011) Photosynthesis and environments: photoinhibition and repair mechanisms in plants. J Plant Biol. doi:10.1007/s12374-011-9195-2

Havir EA, McHale NA (1987) Biochemical and developmental characterization of multiple forms of catalase in tobacco leaves. Plant Physiol 84:450-455. doi:10.1104/pp.84.2.450

Hoagland DR, Arnon DJ (1950) The water-culture method for growing plants without soil. Circular. In: California Agricultural Experiment Station, vol 347. 2nd edn

Johnson GN (2011) Reprint of: physiology of PSI cyclic electron transport in higher plants. Biochim Biophys Acta 1807:906-911. doi:10.1016/j.bbabio.2011.05.008

Johnson MP, Zia A, Ruban AV (2011) Elevated $\Delta \mathrm{pH}$ restores rapidly reversible photoprotective energy dissipation in Arabidopsis chloroplasts deficient in lutein and xanthophyll cycle activity. Planta. doi:10.1007/s00425-011-1502-0

Joliot P, Johnson GN (2011) Regulation of cyclic and linear electron flow in higher plants. Proc Natl Acad Sci USA 108:1331713322. doi:10.1073/pnas.1110189108

Joliot P, Joliot A (2005) Quantification of cyclic and linear flows in plants. Proc Natl Acad Sci USA 102:4913-4918. doi:10.1073/ pnas.0501268102

Kangasjärvi S, Neukermans J, Li S, Aro E-M, Noctor G (2012) Photosynthesis, photorespiration, and light signalling in defence responses. J Exp Bot 63:1619-1636. doi:10.1093/jxb/err402

Klughammer C, Schreiber U (1994) An improved method, using saturating light pulses, for the determination of photosystem I quantum yield via P700+-absorbance changes at $830 \mathrm{~nm}$. Planta. doi:10.1007/BF00194461

Li X-P, Björkman O, Shih C, Grossman AR, Rosenquist M, Jansson S (2000) A pigment-binding protein essential for regulation of photosynthetic light harvesting. Nature 403:391-395. doi:10. $1038 / 35000131$
Lichtenthaler H, Wellburn A (1983) Determinations of total carotenoids and chlorophylls $b$ of leaf extracts in different solvents. Biochem Soc Trans 11:591-592. doi:10.1042/bst0110591

Lieth JH, Reynolds JF (1987) The nonrectangular hyperbola as a photosynthetic light response model: geometrical interpretation and estimation of the parameter-omega. Photosynthetica 21:363-366

Lima Neto MCL, Lobo AKM, Martins MO, Fontenele AV, Silveira JAG (2014) Dissipation of excess photosynthetic energy contributes to salinity tolerance: a comparative study of salt-tolerant Ricinus communis and salt-sensitive Jatropha curcas. J Plant Physiol 171(1):23-30

Lima Neto MC, Martins MO, Ferreira-Silva SL, Silveira JAG (2015) Jatropha curcas and Ricinus communis display contrasting photosynthetic mechanisms in response to environmental conditions. Sci Agric 72:269

Maurino VG, Peterhansel C (2010) Photorespiration: current status and approaches for metabolic engineering. Curr Opin Plant Biol 13:249-256. doi:10.1016/j.pbi.2010.01.006

Maxwell K, Johnson GN (2000) Chlorophyll fluorescence-a practical guide. J Exp Bot 51:659-668

McDowell N, Pockman WT, Allen CD, Breshears DD, Cobb N, Kolb T, Plaut J, Sperry J, West A, Williams DG, Yepez EA (2008) Mechanisms of plant survival and mortality during drought : why do some plants survive while others succumb to drought? New Phytol. doi:10.1111/j.1469-8137.2008.02436.x

Murchie EH, Niyogi KK (2011) Manipulation of photoprotection to improve plant photosynthesis. Plant Physiol 155:86-92. doi:10. 1104/pp.110.168831

Nakano Y, Asada K (1981) Hydrogen peroxide is scavenged by ascorbato specific peroxidase in spinach chloroplasts. Plant Cell Physiol 22:867-880

Nishiyama Y, Allakhverdiev SI, Murata N (2006) A new paradigm for the action of reactive oxygen species in the photoinhibition of photosystem II. Biochim Biophys Acta 1757:742-749. doi:10. 1016/j.bbabio.2006.05.013

Noctor G, Mhamdi A, Foyer CH (2014) The roles of reactive oxygen metabolism in drought: not so cut and dried. Plant Physiol 164:1636-1648. doi:10.1104/pp.113.233478

Ogbaga CC, Stepien P, Johnson GN (2014) Sorghum (Sorghum bicolor) varieties adopt strongly contrasting strategies in response to drought. Physiol Plant. doi:10.1111/ppl.12196

Pérez-Torres E, Bravo LA, Corcuera LJ, Johnson GN (2007) Is electron transport to oxygen an important mechanism in photoprotection? Contrasting responses from Antarctic vascular plants. Physiol Plant 130:185-194. doi:10.1111/j.1399-3054.2007.00899.x

Peterhänsel C, Maurino VG (2010) Photorespiration redesigned. Plant Physiol 155:49-55. doi:10.1104/pp.110.165019

Reid CD, Tissue DT, Fiscus EL, Strain BR (1997) Comparison of spectrophotometric and radioisotopic methods for the assay of Rubisco in ozone-treated plants. Physiol Plant 101:398-404. doi:10.1034/j.1399-3054.1997.1010221.x

Ristic Z, Momcilovic I, Bukovnik U, Prasad PVV, Fu J, Deridder BP, Elthon TE, Mladenov N (2009) Rubisco activase and wheat productivity under heat-stress conditions. J Exp Bot 60:40034014. doi:10.1093/jxb/erp241

Ruban AV (2016) Non-photochemical chlorophyll fluorescence quenching: mechanism and effectiveness in protection against photodamage. Plant Physiol. doi:10.1104/pp.15.01935

Rumeau D, Peltier G, Cournac L (2007) Chlororespiration and cyclic electron flow around PSI during photosynthesis and plant stress response. Plant Cell Environ. doi:10.1111/j.1365-3040.2007. 01675.x

Sage RF, Way DA, Kubien DS (2009) Rubisco, Rubisco activase, and global climate change. Rev Lit Arts Am 59:1581-1595. doi:10. 1093/jxb/ern053 
Saroussi SI, Wittkopp TM, Grossman AR (2016) The type II NADPH dehydrogenase facilitates cyclic electron flow, energy dependent quenching and chlororespiratory metabolism during acclimation of Chlamydomonas reinhardtii to nitrogen deprivation. Plant Physiol. doi:10.1104/pp.15.02014

Scholander (1960) Sap pressure in vascular plants. Science 148:339_ 349

Sejima T, Hanawa H, Shimakawa G, Takagi D, Suzuki Y (2016) Postillumination transient $\mathrm{O}_{2}$-uptake is driven by photorespiration in tobacco leaves. Physiol Plant. doi:10.1111/ppl.12388

Sharkey TD, Bernacchi CJ, Farquhar GD, Singsaas EL (2007) Fitting photosynthetic carbon dioxide response curves for $\mathrm{C}(3)$ leaves. Plant Cell Environ 30:1035-1040. doi:10.1111/j.1365-3040. 2007.01710.x

Stepien P, Johnson GN (2009) Contrasting responses of photosynthesis to salt stress in the glycophyte Arabidopsis and the halophyte Thellungiella: role of the plastid terminal oxidase as an alternative electron sink. Plant Physiol 149:1154-1165. doi:10.1104/pp.108.132407

Suzuki N, Koussevitzky S, Mittler R, Miller G (2012) ROS and redox signalling in the response of plants to abiotic stress. Plant Cell Environ 35:259-270. doi:10.1111/j.1365-3040.2011.02336.x

Takagi D, Hashiguchi M, Sejima T, Makino A, Miyake C (2016) Photorespiration provides the chance of cyclic electron flow to operate for the redox-regulation of P700 in photosynthetic electron transport system of sunflower leaves. Photosynth Res. doi:10.1007/s11120-016-0267-5
Takahashi S, Murata N (2008) How do environmental stresses accelerate photoinhibition? Trends Plant Sci 13:178-182. doi:10. 1016/j.tplants.2008.01.005

Yamori W, Sakata N, Suzuki Y, Shikanai T, Makino A (2011) Cyclic electron flow around photosystem I via chloroplast $\mathrm{NAD}(\mathrm{P}) \mathrm{H}$ dehydrogenase (NDH) complex performs a significant physiological role during photosynthesis and plant growth at low temperature in rice. Plant J 68:966-976. doi:10.1111/j.1365313X.2011.04747.x

Yamori W, Makino A, Shikanai T (2016) A physiological role of cyclic electron transport around photosystem I in sustaining photosynthesis under fluctuating light in rice. Sci Rep 6:20147. doi:10.1038/srep20147

Zelitch I, Schultes NP, Peterson RB, Brown P, Brutnell TP (2009) High glycolate oxidase activity is required for survival of maize in normal air. Plant Physiol 149:195-204. doi:10.1104/pp.108. 128439

Zivcak M, Brestic M, Balatova Z, Drevenakova P, Olsovska K, Kalaji HM, Yang X, Allakhverdiev SI (2013) Photosynthetic electron transport and specific photoprotective responses in wheat leaves under drought stress. Photosynth Res 117:529-546. doi:10.1007/ s11120-013-9885-3

Zivcak M, Kalaji HM, Shao H-B, Olsovska K, Brestic M (2014) Photosynthetic proton and electron transport in wheat leaves under prolonged moderate drought stress. J Photochem Photobiol B 137:107-115. doi:10.1016/j.jphotobiol.2014.01.007 